\title{
Juridical Analysis of the Enactment of Government Regulation on the Right of Assembly in Indonesia
}

\author{
Manotar Tampubolon, Panti Silaban \\ Faculty of Law, Christian University of Indonesia, Jakarta, Indonesia \\ Email address: \\ justitie234@gmail.com (M. Tampubolon)

\section{To cite this article:} \\ Manotar Tampubolon, Panti Silaban. Juridical Analysis of the Enactment of Government Regulation on the Right of Assembly in Indonesia. \\ International Journal of Law and Society. Vol. 3, No. 3, 2020, pp. 123-139. doi: 10.11648/j.ijls.20200303.17
}

Received: July 7, 2020; Accepted: July 21, 2020; Published: August 25, 2020

\begin{abstract}
This article aims to analyze the legal framework of freedom of association in post formation of Law No. 2 of 2017 and Law No. 2 of 2017 on the right to assembly in Indonesia. It is claimed that a number of Civil Society Organization (CSOs) threaten the Indonesian government. Those organizations carry out activities which are contrary to the values of the Pancasila and the mandate of the constitution. This article addresses that revocation of Civil Society Organization is not a violation of human rights, especially the freedom of association and assembly. CSOs must comply with the law and state ideology, Pancasila, as Ground Norm and the 1945 Indonesian Constitution. Those CSOs have carried out acts of hostility including words, statements, attitudes or aspirations verbally which create hatred both towards certain groups and against those who fall into the state administration. Those activities potentially cause social conflict between community members leading to chaotic conditions that are difficult to prevent and overcome by law enforcement officials. Therefore, freedom must be limited.
\end{abstract}

Keywords: Right to Assembly, Violations, Revocation, Civil Society Organization, Forbidden Organization

\section{Background}

The right to freedom of association and assembly is guaranteed constitutionally in Article 28E paragraph (3) of the 1945 Constitution of the Republic of Indonesia (UUD 1945) stating that "Every person has the right to freedom of association, assembly, and expression." [1] It is manifested in Article 24 paragraph (2) of Law Number 39 of 1999 on Human Rights (Human Rights Law) stating that: "Every citizen or community group has the right to establish a political party, non-governmental organizations, or other organizations to participate in the running of government and state administration in line with the guidelines for the protection, enforcement and promotion of human rights in accordance with statutory provisions". [2]

However, there were organizations that carried out activities which were contrary to the values of the Pancasila and the mandate of the constitution. The government considers the development of radicalism understood by a number of CSOs threatens the Indonesian government. Radicalism is interpreted as a view that wants to make fundamental changes in accordance with its interpretation of social realities and ideologies. In this case, radicalism is an act of violence, extreme, and anarchist as a form of rejection of a phenomenon that is encountered. [3] Some indicators of the level of radicalism include, the group hates the Indonesian government for not practicing Islamic Sharia, refusing to sing the national anthem, and refusing to respect the Red and White flag. [4]

Indeed, the counter parties consider the presence of Government Regulation in lieu of No. 2 of 2017 as an authoritarian attitude of the government and inhibits the freedom of the lay community. CSOs as social organizations [5] functions as a means of community participation in the development of the nation and state, for which its existence may not be prohibited. Thus, the content of the rules in Government Regulation in lieu of No. 2 of 2017, which allows the government to revoke legal entities of CSOs without going through a judicial process, is considered to have injured democracy itself. The Government Regulation in lieu of No. 2 of 2017 is considered to be contrary to the principles of the democratic state and violates the principle of checks and balances in a state of taking the role of the judiciary in the process of revocation of a legal entity CSOs. In its development, there was a rejection from various elements of society towards the existence of the Government Regulation in lieu of No. 2 of 2017. 
For instance, general explanation of the Government Regulation in lieu of No. 2 of 2017, there is sociological reason, "The purpose of Government Regulation in lieu of this Act is to distinguish and at the same time protect CSOs that comply with and are consistent with the principles and objectives of CSOs based on Pancasila and the 1945 Constitution of the Republic of Indonesia and CSOs whose principles and activities are clearly in conflict with the Pancasila and the 1945 Constitution of the Republic of Indonesia. Government Regulations in lieu of this Act have separated the two groups of CSOs and are accompanied by extraordinary types of sanctions and their application. The establishment of legal rules regarding mass organizations must follow the principles of protection, equality, justice and uphold the right of association and assembly as mandated by the 1945 Constitution and to protect the people towards the legal ideal that leads people to a just, prosperous life and makes people happy, so that the law will side with the people and side with justice. [6]

\section{Research Problems}

Referring to the aforementioned background, there are 3 (three) main issues that are described in writing this thesis proposal, namely as follows:

a) Has the determination of Government Regulation in Lieu of Law of the Republic of Indonesia Number 2 of 2017 into Law No. 16 of 2017 been qualified to be forced?

b) What are the philosophical, juridical, and sociological considerations in the stipulation of Government Regulation in Lieu of Law Number 2 of 2017 being the Law of the Republic of Indonesia Number 16 of 2017 ?

c) How is the implementation of the right of association after the establishment of the Government Regulation in Lieu of Law No. 2 of 2017 to be the Law No. 16 of 2017 ?

\section{Objectives}

Purwaka states that the research objective is the direction of the research to find answers to problems in the study. [7] Based on the research problems, the overall objectives of this article are:

1. To find out and analyze the fulfillment of urgency requirements that force the establishment of Government Regulation in Lieu of the Law of the Republic of Indonesia Number 2 of 2017 becoming the Law of the Republic of Indonesia Number 16 of 2017.

2. To find out and study the basic philosophical, juridical, sociological considerations of the stipulation of Government Regulations in lieu of the Law of the Republic of Indonesia Number 2 of 2017 becoming the Law of the Republic of Indonesia Number 16 of 2017.

3. To know and analyze the implementation of the right of association after the determination.

4. Of Government Regulation in Lieu of Law of the Republic of Indonesia Number 2 of 2017 to the Law of the Republic of Indonesia Number 16 Year 2017.

\section{Theoretical and Conceptual Framework}

\subsection{The rule of Law Sovereignty}

Sovereignty comes from the Latin word: "superanus" which is synonymous with supernius or hyperbus or superus meaning the highest point. Sovereignty was first introduced by Jean Bodin in 1576, by deciphering sovereignty as "the state roommates made its essential characteristic of sovereign power." [8] Strong mentions that the state has power to make and implement laws by force. [9] The views by Bodin and Strong above basically recognize that the owner of sovereignty is the state because the state makes and implements all the rules that it makes. The theory of legal sovereignty having the highest authority in a country is the law itself, both the king, the ruler, and the people even the country itself are subjects to law. All attitudes; behavior and actions must be according to law "[10]. Krabbe stated that the essence of rule of law is: "The law is not at all dependent on human will, even the law is something that is independent of human desire." The law is in everyone's legal awareness. Legal awareness is not forced from the outside but is felt by people inside themselves. That awareness compels people to adjust all their actions with that legal awareness. [11] Hartono argues that law is the source of state power. [12] Therefore, the duty of the state is to embody legal awareness in the form of positive tangible legal provisions of legal regulations. Thus, the theory of the rule of law brings the consequence that every power in the state must be subject to the law. If the law is the highest authority in the state by holding to the core theory of the rule of law, the judiciary must also submit to the law. The consequence of all powers under the rule of law must also be subject to law. This also applies in emergencies or forced situations.

\subsection{The Theory of Rule of Law}

In relation to the highest power in a country, according to the understanding of democracy, the highest power is in the norm or the sovereign is the norm or law. Previous thinker such as Plato, clearly illustrated how the idea of a real nomocracy, which has long been developed from the days of Ancient Greece. [13] Hadjon, also states that the concept of rechtsstaat was born from a struggle against absolutism; thus, it was revolutionary while the rule of law was developed evolutionarily. [14] Meanwhile, Dicey described the existence of three important characteristics in each rule of law namely: Supremacy of Law, Equality before the law, and Due Process of Law. Mahfud MD. says that the truth of law and justice in rechtsstaat lies in the provisions and even written evidence. A good judge, according to understanding civil law (legism), is able to implement or make decisions in accordance with the sound of the law. Yamin argues that the Republic of Indonesia is a state of law (rechtsstaat government of laws) where written justice applies; it is not a police state or military state, where police and soldiers hold government and justice, nor it is a state of power (rechtsstaat) where weapons and body strength 
do arbitrarily. [15]

The Republic of Indonesia is not only rechtsstaat but also the rule of law. Therefore, the removal of the phrase rechtsstaat after Amendment of 1945 Constitution is not only semantic or grammatical matters but also as substantive and paradigmatic matters. It is known that there are two different terms namely rechtsstaat and the rule of law. The two terms are translated into Bahasa Indonesia in the same term, the rule of law, though both terms the rechtsstaat and the rule of law have different concepts and institutions. [16] Asshiddiqie says if the law is understood rigidly and narrowly in the sense that it is only a statutory regulation, surely the notion of a developed rule of law is also narrow and limited and does not necessarily guarantee substantive justice. Therefore, in addition to the term the rule of law by Friedman, the term 'rule of just law' is also developed to ensure that in our understanding of the rule of law a more essential understanding of justice than just the functioning of laws and regulations in narrow meaning. It is emphasized that even if the term used remains the rule of law, that broad understanding is expected to be included in the meaning of the rule of law used to refer to the conception of the rule of law today. [17]

Furthermore, as a state of law, Indonesia accepts the principle of legal certainty in rechtsstaat as well as the principle of a sense of justice in the rule of law and the spiritual value of religious law. The written law with all such procedures must all be put in the context of upholding justice. Therefore, written provisions that can prevent the realization of justice can be abandoned. [18] Utrecht distinguishes formal and statutory rule of law, and material rule of law or modern rule of law. [19] The formal rule of law or classical rule of law involves the definition of law that is formal and narrow. In this case, the law is only seen from written legislation. Whereas the state of material law or the state of modern law, i.e. the state of material law, which is more recent, also includes the notion of justice in it. Friedman distinguishes rule of law in the formal sense, i.e. in the sense of 'organized public power', and rule of law in the material sense, i.e. 'the rule of just law'. This distinction is intended to emphasize that in the concept of the rule of law, justice will not necessarily be realized substantively, because people's understanding of the law itself can be influenced by a range of formal legal understandings and can also be influenced by the flow of material law. [20]

\subsection{Concept of Right of Association}

Human rights are basic rights inherent in human nature, universal and lasting as a gift from God Almighty, including the right to life, the right of family to continue descendants, the right to develop themselves, the right to justice, the right of freedom, the right of security, and welfare rights that function to maintain the integrity of its existence, so that no one can be ignored and deprived. It is said to be 'inherent' because those rights are possessed naturally since being born as a human being instead of being granted by any organization of power including the state. It is said that it is 'attached', so basically these rights cannot be taken for a moment or revoked. The formula clearly recognizes that human rights are gifts from God Almighty and the State of Indonesia recognizes that the source of human rights is the gift of God. The strictness of human rights including the right to freedom of association is not a gift from the state but a gift from God. [21]. In Maurice Cranston's language, it is stated "Absolutism prompted man to claim rights precisely because it denied them". [22]. Vasak as cited by Asshidiqie [23] mentions the First Generation represents civil and political rights, i.e. "classic" human rights. These rights arose from the demand to free themselves from the confinement of state absolutism and other social forces.

Moreover, the peak of human rights protection in Indonesia began with the amendment to the 1945 Constitution indicated in the adoption of the first to fourth amendments of the 1945 Constitution in 2002, which is contained in Chapter XA on Human Rights, articles 28A to 28J. The 1945 Constitution guarantees the rights and freedom of association and assembly and issues opinions for every citizen in social life and this is part of human rights. [24] The CSOs as a forum for association and assembly is a form of collective awareness and responsibility of citizens to participate in the country's development. So that, the state, in this case, is obliged to recognize the existence of CSOs, provide protection for its activities, and guarantee the survival of CSOs.

On the other hand, every citizen both collectively and individually in exercising their rights and freedoms must also respect the rights and freedoms of others. It is, in this context, that the state is obliged and must be able to regulate the balance and harmony between the rights and freedoms of individuals with the collective rights and freedoms of citizens. The regulation is intended solely to guarantee the recognition and respect for the rights and freedoms of others, and the fulfillment of justice in accordance with moral considerations, socio-cultural values, religion, security, peace and public order to maintain the sovereignty of the Unitary State of the Republic of Indonesia. Therefore, the Government is obliged to maintain that $\mathrm{CSO}$ activities remain in the corridor of applicable law, both positive law and norms, values, morals, and ethics applied in society. Arrangements made by the Government are intended to ensure that freedom of association and assembly, which are human rights for citizens, must not override the rights and obligations of citizens to practice and strengthen the state ideology. Therefore, the Government regulation is directed to avoid the potential freedom of mass organizations to be used to spread ideologies that threaten the ideology of the nation. [24. Para 4]

In relation to the restrictions on freedom as discussed above, Russell believes that the most appropriate tools and systems for regulating freedom are law and government. [25] Using this basis, human freedom can and should be limited by law. Furthermore, restriction by law can be justified, because theoretically public recognition of the limitations of his freedom through the law and based on the law has the function of regulating and realizing a better life order. In 
addition, the law is made with the aim to limit state power. [25 para. 45] Restrictions on citizens' power are usually stated in the constitution where the constitution has the aim to control the state or government from the possibility of arbitrary actions or abuse of power, both by the governing and the governed.

The state's authority to limit the right to associate is also confirmed by the Constitutional Court in the Constitutional Court Decision No. 82/PUU-XI/2013 on the Examination of Mass Organizations of the 1945 Constitution in which the Constitutional Court is of the opinion: “... if the activities of CSOs are proven to threaten public order and security, interfere with the rights of freedom of others, and violate moral values and religious values, the state is obliged to function in ensuring that public order can enforce law, and even stop the activities of an organization."

Provisions in the ICCPR and the 1945 Constitution show that the government based on law has a role to do to restrict freedom of association if such freedom can actually threaten national security and public order.

\section{Research Method}

The author used descriptive study aiming to study the legal norms relating to CSOs issues based on statutory provisions in Indonesia. Normative legal research methods or library legal research methods used in legal research were conducted by examining existing library materials. [26] The secondary data were obtained, processed and analyzed using qualitative method. This method produces descriptive analysis data, stated by respondents either written or spoken and real behavior, which is studied as something intact. [26 para. 41]

\section{General Review of Replacing Law Number 2 of 2017 to Be Law Number 16 of 2017}

\subsection{The Concept of Establishment of the Government Regulation in Lieu of No. 2 of 2017 to Be Law No. 16 of 2017}

The concept of the rule of law in Indonesia is a concept of the rule of law developed and applied in Indonesia. The concept of the Indonesian legal state is based on the Pancasila legal system. In other words, the concept of the rule of law of Indonesia has the characteristics found in the philosophy of the nation and the state of Indonesia, namely the philosophy of Pancasila. The existence of Pancasila as state philosophy that serves as filosofhische gronslag and common platforms or Kalimatun Suwa among the citizens of society should be populist in the context of a buffer state in the first deal of constitutionalism shows open nature of Pancasila as an ideology. [27]

Another equally important that the concept of the rule of law is inseparable from the pillar, namely the concept of the rule of law. The theory of the rule of law was pioneered by
Krabbe denying the theory of state sovereignty. In the theory of state sovereignty, law is placed lower than the state, which means that the law must submit to the state because the law is an order rather than the state. This is refuted by Krabbe, according to him, sovereignty does not lie in the state but lies in the law itself. Therefore, both the authorities and the people even the country itself must submit to the law.

The formation of laws and regulations need to pay attention to certain limitations in order to achieve the goal of forming legislation. [28] Flores stated that those limits are 8 (eight) principles, namely: (1). Generality: law must be general not only by creating general and abstract cases, but also by promoting the common good or interest; (2). Publicity: law must be promulgated in order to be known by its subject; (3). Non-retroactivity: laws must not be applied ex post facto; (4). Clarity: the law must be clear and precise in order to be followed; (5). Non contradictory: law must be coherent and without (logical) contradictions or inconsistencies; (6). Possibility: law must not command something impossible and therefore not must be given a (merely) symbolic effect; (7). Constancy: law must be general not only in their creation, but also in their application, and hence law should not be changed too frequently or enforced intermittently; and (8). Congruency: law must be applied according to the purpose for which they were created, preventing any discrepancy between the law as declared and it is actually enforced. In addition, there are three types of principles that are relevant to the formation of laws and regulations, namely: Substantive principles related to the contents of laws and regulations, Formal principles related to the form of laws and regulations and, Procedural principles related to institutions and processes that are passed for the formation of laws and regulations. [29]

\subsection{General Review Regarding the President's Prerogative in the Establishment of the Government Regulation in Lieu}

It is not easy to formulate an understanding of prerogative powers, both because of their historical sources as legal institutions and their scope. At present, prerogative powers are increasingly limited, either because they are regulated by law or restrictions on how to implement them. Some circles view the prerogative as a remnant from the era of authoritarianism before the enlightenment in Europe. On June 15, 1215, when King John was enthroned, the wind of change blew when the Magna Charta was ratified. The charter contains the special privileges of high aristocrats. The charter is considered a milestone that began the efforts of the people's participation in power management. After the Charter was released, slowly but surely, the power of the king or the king of England was getting smaller. All cuts are included in the law. The prerogative is the power left in the hands of the king or queen and is not regulated by law. In the meantime, practically the king or king of England is only a symbol. In the practice of state administration, its role is almost zero. The form of prerogative right that is still being used by the king, for example, bestows a noble aristocratic 
title on someone. [30]

Dicey argues that the prerogative rights are historically actual facts, it seems that they are nothing but residues from the power of the queen/king's discretion, which is legally left alone and exercised by the queen/king and ministers. [31] It is deemed as residuals because this power is none other than the rest of the power that all belongs to the queen/king (absolute power) which then diminishes and switches to the hands of the people (parliament) or other government elements, such as ministers. Prerogative power comes from common law, which is an unwritten law derived from a judge's decision. Because it does not require a legal basis, some prerogative powers are seen as undemocratic and potentially dangerous. [31 para. 61]

The interpretation of prerogative rights as one of the powers of the President often creates differences and debate. Fatovic expressed his opinion that: "scholars, the courts, and the public have been ambivalent in the meaning of prerogative as president power to take extraordinary measures (extraordinary) with no law that explicitly regulates it, and it is sometimes at odds with the principle of constitutionalism. [32] Mahfud mentions that the President's prerogative is the privilege that the President has to do something without asking for the approval of other institutions. [33] The granting of prerogative rights to do certain things for the President is partly a consequence of the adoption of the understanding of the material state law (welfare state). [33 para. 259] The functions and duties of the government are so broad that they no longer merely implement the law but do various things according to their own creations and authorities to build the welfare of society. For this reason, an authority institution called Freies Ermessen was created, thus, the government in the rule of law is demanded to be active, so that for states that are welfare states, Freies Ermessen appears as an alternative to fill the deficiencies and weaknesses in the application of the principle of legality (wetmatigheid van bestuur). The freedom given to the state administration in the framework of governance is now in line with the increasing complex demands for public services.

Furthermore, regarding the constitutional authority to issue the Government Regulation in lieu, according to Rossiter, there are some important notes considering an authority to be Constitutional Dictatorship. The character of constitutional dictatorship is the existence of a delegation of powers to form laws (delegated legislation) temporarily to the president on basis of a condition of emergency. The authority is usually limited in a certain time and for certain reasons, although with certain conditions there are also permanent. [34]

The prerogative granted by the constitution to the President to issue the Government Regulation in lieu in emergency condition is based on the provisions of Article 22 of the 1945 Constitution and Article 1 paragraph (4) juncto Article 7 paragraph (1) letter c of Law Number 12 of 2011 on Formation of Legislation Regulations in line the International Covenant on Civil and Political Rights -ICCPR) [35] has regulated various human rights within the scope of civil and political rights. The provisions of Article 22 paragraph (1) of the ICCPR guarantee the right of everyone to associate with others, including the right to form and join trade unions to protect their interests. These rights cannot be limited unless limited by law with the aim at the interests of national security and public safety, public order, protection of public health and morals, or protection of the rights and freedoms of others as stipulated in the provisions of Article 22 paragraph (2). The provisions in the ICCPR affirm the position of the rights of association as derogable rights.

\section{Philosophical, Juridical, and Sociological Foundations of Government Regulations}

\subsection{Philosophical Basis for Establishing the Government Regulation in Lieu of No. 2 of 2017 Becomes Law Number 16 of 2017}

Theoretically, the basis for establishing the Government Regulation in lieu of No. 2 of 2017 becomes Law Number 16 of 2017 must be based on Pancasila. It is also as the basis of state philosophy (philosophical grondslag), state ideology and way of life which is a source of values, inspiration and basis for the interpretation of community, nation and state life which is actualized into the process and all products of legislation and various policies state administration. Pancasila is also a sign for the implementation of good and right national and state management (good governance). In order to step towards the right state governance, Kuntowijoyo offered a process of "radicalization of Pancasila" intended for: (1) returning Pancasila as the state ideology, (2). developing Pancasila as an ideological logic into Pancasila as science, (3). trying to Pancasila as consistency with the product of legislation, coherence of the precepts, and correspondence with social reality, (4) Pancasila which initially only serves vertical interests (the state) becomes Pancasila that serves horizontal interests, and (5) makes Pancasila as a critique of policy right country. [36]

In the context of strengthening the internalization of the values of Pancasila, the most important thing in this first phase is the step to optimize the existence of an academic text of a draft. [37] Academic texts contain at least a philosophical, sociological, juridical basis, as well as subject matter and materials that are governed by the attention to the philosophical basic aspects of this matter which are the focus and point of view in making Pancasila as its philosophical basis. Therefore, in the academic text, there should be a special section that explicitly lists in full the connectedness of Pancasila values with the draft/ that is being prepared by placing guiding rules that cannot be separated from Pancasila values. [37 para. 63]

The second stage is joint discussion between the legislature and the executive. In this stage, everything is possible, at least there are three possibilities, namely: (1) the design submitted will experience changes, (2) the proposed 
design has not changed or improved, (3) the design is rejected. At this stage, strengthening the internalization of Pancasila can be used as one way to do quality control on the sub's militancy draft legislation discussed.

At the stage of mutual agreement, that in the legislation system adopted, Article 20 Paragraphs (2) and (3) of the 1945 Constitution illustrate that the position of the People's Representative Council (DPR) and the President is equally strong in the approval of the draft law. With such a position, the president and the Parliament should be able to use that position as a "weapon" to guard the internalization of the values of the Pancasila, meaning that if the results of the joint discussion threaten Pancasila, the President and the Parliament must use them as an excuse to reject the contents of the bill. If that is done, the refusal to approve the bill has a strong philosophical basis. [37 para. 63]

\subsection{Juridical Basis for Establishing the Government Regulation in Lieu of No. 2 of 2017 Becomes Law Number 16 of 2017}

One of the basic human rights guaranteed by the 1945 Constitution is freedom of association and assembly, which is regulated in Article 28E paragraph (3) of the 1945 Constitution which states that Every person shall have the right to the freedom of association, assembly, and expressing opinions. The provision of Article 28E paragraph (3) of the 1945 Constitution contains a much firmer substance compared to the original formulation of Article 28 before the second amendment of 2000 which reads "Freedom of association and assembly, expressing opinion orally and in writing and so forth stipulated by law."

According to Asshiddiqie, if the provisions on guarantee of the right to associate are stipulated by law, it means that the guarantee will only come after the stipulation by law. [38] Article 28 of the 1945 Constitution is deemed not to contain guarantees of human rights as should be the content of the constitution in a democratic country. The formulation of this provision is different from Article 28 E paragraph (3) of the Second Amendment to the 1945 Constitution in 2000 which recognizes freedom of association firmly. The formulation of Article 28 E paragraph (3) of the 1945 Constitution is closely related to the history of universal human rights instruments that freedom of expression is regulated sequentially in one article, as found in the Universal Declaration of Human Rights and the International Covenant on Civil and Political Rights. Article 20 paragraph (1) of the Universal Declaration of Human Rights stipulates that "everyone has the right to freedom of peaceful assembly and association", while the provisions in the International Covenant on Civil and Political Rights mentions "the right of peaceful assembly" in article 21 and "freedom of association" in article 22.

Protection of the rights and freedoms of association and assembly to express their opinions is only provided as long as the exercise of these rights and freedoms is carried out peacefully. The limitation of human rights allowed in the constitution or the 1945 Constitution can be seen in Article 28J paragraph (2) which stipulates that the limitation is carried out by law only with the aim to (i) protect and respect the rights and freedoms of others, and (ii) meet fair demands based on moral considerations, religious values, security and public order. [39]

The development of CSO's arrangements in Indonesia is to accommodate CSOs through Law No. 8 of 1985. The law regulates some restriction, especially ideological restriction which strictly requires the placement of Pancasila as the sole state principle. In addition, according to these regulations, the government can freeze and/or dissolve the board of CSOs without legal process if CSOs engage in activities that disrupt public order and security, receiving assistance from foreign parties without government approval, and provide assistance to the adverse foreign state interest. Transparency and public accountability are also bad values for most CSOs in Indonesia. In addition, some CSOs are very dependent on the government or other parties (home and foreign) to support all of their activities. Concerns about the role and position of CSOs as described above have led to the birth of a new mass organization law as a strong regulation for the existence of CSOs in Indonesia.

In its development, some organizations were considered to be in contradiction with the Pancasila and the 1945 Constitution, while some organizations were considered to be inappropriate in the Article of Association registered and endorsed by the government. This was actually regulated in Law No. 17 of 2013 however the existence of Law No. 17 of 2013 is considered not yet to comprehensively regulate CSOs that are considered to be in conflict with Pancasila and the 1945 Constitution. Thus, a legal vacuum arises in the case of applying effective sanctions for CSOs that are considered to be in conflict with Pancasila and the 1945 Constitution. Then, the government takes quick steps to curb mass organizations in Indonesia by issuing the Government Regulation in lieu of No. 2 of 2017 on the change of Law No. 17 of 2013 issued and on signs deal with the President on July 10, 2017 and was passed by Parliament as legislation through a plenary meeting on 24 October 2017 and Government Regulation No. 2 of 2017 later stipulated to become Law No. 16 of 2017.

There are several changes to Law No. 17 of 2013 regulated in Law No. 16 of 2017 juncto the Government Regulation in lieu of No. 2 of 2017, among others: changes in Article 1 paragraph 1, Article 59, Article 60, Article 61, Article 62, and the explanation of Article 59, Article 63-81 is deleted, new articles including Article 80A, Article 82A and Article 83A, and the existence of Chapter XVIIA.

There are some considerations for the issuance of the Government Regulation in lieu of No. 2 of 2017 which has now become Law No. 16 of 2017. First, Law No. 17 of 2013 was urgent to be done because the changes have not yet set comprehensively on all CSOs which are contrary to Pancasila and the 1945 Constitution; thus, there is a legal vacuum in terms of the application of effective sanctions. Second, there are certain CSOs whose activities are not in line with CSO principles and the articles of association that have been registered and approved by the Government, and were even proven conflict with Pancasila and the 1945 Constitution. 
Third, the Law No. 17 of 2013 has not adhered to the principle of contract us actus so it is not effective in applying, adhering to, developing, and spreading teachings or understandings that are contrary to Pancasila and the 1945 Constitution. [40].

\subsection{The Sociological Basis for Establishing the Government Regulation in Lieu of No. 2 of 2017 Becomes Law Number 16 of 2017}

The dynamics of the development of CSOs experience metamorphosis in line with the development of human civilization, science and technology, law, and state governance that includes changes in the arable sector as well as ways of carrying out activities and relationships with the environment. In the history of the struggle for independence of the Republic of Indonesia, CSOs are the main place in the independence movement, including the Boedi Oetomo, Muhammadiyah, Nahdlatul Ulama, and other mass organizations established before the independence of the Republic of Indonesia. The role and track record of CSOs that have fought willingly and voluntarily carried historical value are national assets and important for the journey of the nation and state.

In carrying out these freedoms, organizations are free to do anything though it is prone to abuse and deviation. The abuse conducts by CSOs include: as a place for money laundering, as an instrument of political interests, while deviations include as a vehicle for terrorist movements and radical movements that threaten national security and unity. [41] In order to prevent abuse and deviation (misuse) of freedom of association as well as tackling the growing radicalism in Indonesia, the Government has established the ideology of Pancasila Development Agency. The duties and functions of the Pancasila Ideology Development Board (BPIP) are based on Presidential Regulation No. 7 of 2018 on the Pancasila Ideology Development Board (BPIP).

Although the government has long established an institution to instill the values of Pancasila in the community and currently the state has a BPIP, misuse of CSOs that have led to radical movements such as those mentioned above still exists and can jeopardize state integration. There are some CSOs who want to separate themselves from the Homeland or change the Homeland into a state system running on their ideology. These harmful teachings can come from political ideologies, philosophies, and religious teachings that are contrary to Pancasila. For example, the Hizbut-Tahrir Indonesia Community Organization (HTI) has the ideology of Islam religion and opposes Pancasila. According to HTI's belief, Law of Islam is impossible to be implemented perfectly except with the existence of Islamic state and a caliphate. [42]

In the context of Indonesia, the existence of HTI is different from the existence of NU and Muhammadiyah, which arose as a result of the local dynamics in Indonesia. If it is related to the dimensions and general objectives of these two organizations which accentuate Indonesian Version of Islam, HTI's transnationalism ideology is more representative of the Islamic centrifugalism movement. HTI's vision is to unite national and local Islamic identities scattered throughout the world under the sole authority of the Islamic Khilafah. The doctrine is recognized by HTI activists as an ideological antithesis that is ready to rival, even replace the position of the concept of the state and nation of the Republic of Indonesia which is considered final in Indonesia. [43]

There are some considerations for the issuance of the Government Regulation in lieu of No. 2 of 2017 which has now become Law No. 16 of 2017. First, that Law No. 17 of 2013 was urgent to be done because the changes have not yet set comprehensively on all CSOs which are contrary to Pancasila and the 1945 Constitution; thus, there is a legal vacuum in terms of the application of effective sanctions. Second, there are certain CSOs whose activities are not in line with CSO principles and the articles of association that have been registered and approved by the Government and were even proven conflict with Pancasila and the 1945 Constitution. Third, the Law No. 17 of 2013 has not adhered to the principle of contract us actus so it is not effective in applying, adhering to, developing, and spreading teachings or understandings that are contrary to Pancasila and the 1945 Constitution.

According to Coordinating Minister for Political, Legal and Security observation and through a regulatory process that is long and detailed, the missionary movement CSO HTI has entered the realm of politics and the real threat to sovereignty of the Unitary Republic of Indonesia since they carry the ideology of the caliphate. There are at least 3 reasons behind the government's policy to dissolve HTI. First, HTI is seen as not carrying out a positive role to take part in the development process in order to achieve national goals. Second, the activities carried out by HTI have been indicated to be strongly opposed to the objectives, principles, and characteristics of association and assembly activities based on the Pancasila and the 1945 Constitution. Third, the activities carried out clearly have caused conflicts in the community that can threaten public security and order and endanger the integrity of the Republic of Indonesia. Based on these sufficient reasons, HTI has been officially dissolved through a Decree of the Ministry of Law and Human Rights Number AHU-30. AH. 01.08 of 2017 on Revocation of the Decree of the Minister of Law and Human Rights regarding the Ratification of the Establishment of a Legal Entity of HTI. Once the legal status was revoked, HTI filed a lawsuit to cancel the decree revocation of legal status to the State Administration Court with No. 211/G/2017/PTUN-JKT verdict issued on May 7, 2018 and be rejected. Moreover, on appeal No. 196/B/2018/HTI went back to PT. TUN. JKT and they should accept defeat since the appeal verdict Administrative Court upheld the verdict. At the cassation level, the panel of judges stated in their judgment that the Judex Factie decision in the case was not contrary to the law and considered violations committed by HTI and used the Pancasila historical approach as a state foundation. Thus, for Case No. 27/K/TUN/2019, panel of judges declared their opposition to the cassation of HTI. 
In addition, some CSOs were disbanded by the government such as Jamaah Ansharut Daulah (JAD) which was proven to be involved in terrorist activities. JAD is the second terrorist organization in Indonesia, after Jemaah Islamiyah which was tried as a banned group. JAD was formed November $15^{\text {th }}, 2015$ in which they agreed to unite supporters of the caliphate and help fight ISIS in Syria. In the trial, JAD was considered responsible for a series of terror that occurred such as the Thamrin bombing in Central Jakarta, the Malay village in East Jakarta, the Ouikumene Church in Samarinda, the attack on Central Office of Brigade Mobile and the suicide bombing in Surabaya. The South Jakarta District Court Panel of Judges finally officially dissolved the JAD organization in its decision. [44]

Based on the facts from the examples of the two CSOs' activities above, Law No. 17 of 2013 is no longer considered adequate as a means to prevent the spread of ideologies that are in conflict with the Pancasila and the 1945 Constitution, both from the substantive aspects related to norms, prohibitions, and sanctions as well as existing legal procedures. The understanding of teachings and actions that are contrary to Pancasila is narrowly formulated, which is only limited to the teachings of Atheism, Marxism/communism, and Leninism. However, there are CSOs that develop understanding or ideologies and teachings that are contrary to the Pancasila and the 1945 Constitution. Those are not included in the understanding of atheism, communism, Leninism, Marxism which is developing rapidly in Indonesia.

Furthermore, the contrario actus administrative law is not encompassed, i.e. the legal principle of the agency that issues permits or gives authorization is the institution that should have the authority to revoke or cancel it. Therefore, the Government issued Regulation No. 2 of 2017 on Amendment to Law No. 17 of 2013 and then stipulated it into the Law No. 16 of 2017 . The legal vacuum cannot be overcome by making the Act in an ordinary procedure because it requires a long time while the urgent situation needs to be resolved immediately. Meanwhile, waiting for revision of Law No. 17 of 2013 will certainly take a long time. Therefore, it is urgent to act decisively and immediately.

\section{Implementation of the Rights of Assembly After Determination of the Replacement Government Law}

\subsection{Urgent Situation Category as the Basis for Establishing Government Regulations in Lieu of Law Number 2 of 2017 Becoming Law Number 16 of 2017}

The existence of CSOs is a logical consequence of the formation of legislation containing the concept of freedom guaranteed by the constitution. The 1945 Constitution provides an explanation of the protection and reference for the issuance of a law on social organization in Indonesia, guarantees of freedom of association, assembly, and expressing opinions, and advancing itself in fighting for individual or collective rights to develop communities, nations, and countries as the embodiment of human rights.

In exercising these freedoms, the 1945 Constitution guarantees protection through Article 28J paragraph (2) stating that In exercising his/her rights and freedoms, every person shall have the duty to accept the restrictions established by law for the sole purposes of guaranteeing the recognition and respect of the rights and freedoms of others and of satisfying just demands based upon considerations of morality, religious values, security and public order in a democratic society.". The constitution has set limits on these freedoms, as an effort to respect and protect human rights. Therefore, the government is based on the authority guaranteed by the constitution in carrying out interpretations and assessments in limiting these freedoms.

Some indicators of the radicalism level can be seen from a number of conditions that have just occurred, such as the group does not agree with the Indonesian government because it does not run Islamic Sharia or the caliphate state, refuse to sing the national anthem, and refuse to respect the Red and White flag. [33 para 8] In addition, emergencies that can threaten the country's sovereignty are defined in, among others, the activities of social organizations that have carried out hostile actions, such as words, statements of attitude, aspirations both written and oral expressed through electronic media or not through electronic media, which can cause resentment towards certain groups and those who belong to the state administration.

The government is aware that the existence of radical groups has begun to disturb public order and should issue a regulation that can replace Law No. 17 of 2013. As an effort to overcome radicalism and to strengthen the important foundation of the Unitary State of the Republic of Indonesia by instilling the noble values of Pancasila, Unity in Diversity, and the 1945 Constitution in the life of society, nation and state, the Government Regulation in lieu of No. 2 of 2017 is the prerogative of the President guaranteed by the constitution in Article 22 paragraph (1) of the 1945 Constitution stating that provision provides a prerogative for the President to take action in an emergency.

The formulation in the provisions of Article 22 paragraph (1) of the 1945 Constitution which states that in the case of compulsion concerns, the President has the right to determine government regulations in lieu of laws [45], has provided a clear understanding that the intended government regulation is a substitute for the law. This means that the material should be regulated in the legal framework called a substitute for the law since the formulation of the law requires a relatively long time. The prerogative of the President in issuing the Government Regulation in lieu must be tested whether it meets the provisions and is appropriate in an emergency. There is a debate whether the Government Regulation in lieu of No. 2 of 2017 has fulfilled the requirements to be categorized in an emergency or urgency that has forced or has not yet fulfilled these requirements.

The 1945 Constitution and Law No. 11 of 2012 do not 
provide an explanation of the definition of 'forced urgency' in the article formulation. However, the assumption for the interpretation of 'compelling urgency' in establishing the Government Regulation in lieu is entirely subjectively to the President as the holder of the current authority that can be annulled by the existence of 3 (three) parameters in Decision Number 138/PUU-VII/2009 which must be an objective indicator for the President in establishing it. It needs to pay attention to the intention and purpose of the Government Regulation in lieu of No. 2 of 2017.

The urgent situation to resolve legal issues quickly based on the law is one of the parameters contained in the Constitutional Court Decision Number 138/PUU-VII/2009, so as to be able to enact an emergency or dangerous state (state of emergency, state of exception, etat de siege.) Asshiddiqie stated that it is required to fulfill the following formal requirements: [46] In addition to the formal requirements, there are also material requirements that must be met for the stipulation of the Government Regulation in lieu, namely: there is an urgent need to act or reasonable necessity, the time available is limited or there is time crunch, and no alternative available is estimated to be able to overcome the situation, so the enactment of the Government Regulation in lieu is the only way to overcome the situation. [47]

If it is reviewed from the hierarchy of laws and regulations in Article 7 paragraph (1) of Law No. 12 of 2011, the Government Regulation in lieu has been put on an equal basis with the law. Furthermore, in Article 11 of Law No. 12 of 2011 on material charge, the material for the content of the Government Regulation in lieu is the same as the material contained in the law. Because the Government Regulation in lieu is a government regulation that replaces the position of the law, Soeprapto [48] stated that the material contained in the Government Regulation in lieu is the same as the material contained in the law. Meanwhile, Manan stated that the material contained in the Government Regulation in lieu is the material contained in the law, and must be regulated by law. However, due to an urgent need to be regulated by the Government Regulation in lieu [49] the understanding of 'matters of urgency' is also interpreted as 'urgent interests' with criteria: (1). Only issued in the case of compulsion concerns, (2). The Government Regulation in lieu may not regulate matters regulated in the 1945 Constitution or the provisions of the People's Consultative Assembly, (3). The Government Regulation in lieu may not regulate the existence and tasks of the authority of state institutions. There should be no regulation that can delay or revoke the authority of state institutions, and (4). The Government Regulation in lieu only regulates the provisions of laws relating to the administration of the state.

Based on the above description, the President interprets the existence of urgency on the basis of an urgent situation to be immediately amended on the basis of an emergency that can threaten the sovereignty of the Unitary Republic of Indonesia based on Pancasila and the 1945 Constitution, [50] Therefore, the Government Regulation in lieu of No. 2 of 2017 can also be regarded as an emergency regulation issued by the President with the limitation that the Government Regulation in lieu of is issued in 'matters of urgency'. Thus, it is not limited to situations containing a concern or threat but includes 'matters of urgency. In this case, it is not only limited to circumstances that contain a concern or threat but also includes needs that are deemed urgent.

Issuance of the Government Regulation in lieu of No. 2 of 2017 is inseparable from the existence of urgency and emergency situations. This condition was the background for the enactment of the Government Regulation in lieu of No. 2 of 2017 for reasons that are deemed to threaten the sovereignty of the Unitary State of the Republic of Indonesia as contained in the Explanation section of the Government Regulation in lieu of No. 2 of 2017 stating that: [50 para 3]

"Emergencies that can threaten the sovereignty of the Unitary State of the Republic of Indonesia based on Pancasila and the 1945 Constitution of the Republic of Indonesia include certain CSO activities that have carried out acts of hostility such as words, statements, attitudes or aspirations both verbally and in writing, through electronic media or not using electronic media, which causes resentment towards certain groups and those who belong to state administrators. This action is a potential action to cause social conflict between community members so that it can lead to chaos that is difficult to prevent and overcome by law enforcement officers."

The Government Regulation in lieu of No. 2 of 2017, in the elucidation section, quotes the Decision of the International Constitutional Court of the Covenant on Civil and Political Right (ICCPR) in its explanation. It can be interpreted that what is meant by 'matters of coercive urgency' is a threat to the future life of the Indonesian nation and the existence of the Republic of Indonesia.

\subsection{The Legal Void Category as the Basis for Establishing Government Regulations in Lieu of Law Number 2 of 2017 Becoming Law Number 16 of 2017}

Forcing interests as formulated in the provisions of Article 22 paragraph (1) of the 1945 Constitution cannot be interpreted limited only because of the danger situation as referred to in Article 12 of the 1945 Constitution stating that: [51] "The president declared a state of danger. The conditions and consequences of a hazard are determined by law." The state of danger as referred to in Article 12 of the 1945 Constitution may cause the process of forming laws normally could not be carried out, but the state of danger is not the only condition that causes the emergence of a compelling urgency as referred to in Article 22 paragraph (1) of the 1945 Constitution.

After the urgent need to resolve legal issues quickly based on the law, the next parameter contained in the Constitutional Court Decision Number 138/PUU-VII/2009 is the Second Parameter. It is the required Acts that do not yet exist so that there is a legal vacuum, or there is the law but is inadequate, as stated in the Consideration letter e the Government Regulation in lieu of No. 2 of 2017 stating that: "Law 
Number 17 of 2013 on Community Organizations has not adhered to the principle of contrarius actus so that it is not effective in applying sanctions against social organizations that adhere to, develop, and spread teachings or understandings that are in conflict with the Pancasila and the 1945 Constitution of the Republic of Indonesia."

The contrarius actus principle is the principle of administrative law which forms the legal basis for the issuance of the Government Regulation in lieu of No. 2 of 2017. Institutions that issue licenses or authorize CSOs have the authority to revoke or cancel them. The substance of Government Regulation No. 2 of 2017 is the existence of government authority to impose sanctions on CSOs that are considered not in line with the spirit of Pancasila and the 1945 Constitution. In fact, the management can be subject to criminal sanctions.

With various considerations based on real events in the field, the government provides changes in CSO arrangements in Indonesia related to dissolution and sanctions originally stipulated in Law No. 17 of 2013. In the Government Regulation in lieu of No. 2 of 2017, the dissolution of CSOs can be carried out by the Minister of Home Affairs by revoking Registered Certificate (SKT) and/or by the Minister of Law and Human Rights through revocation of the status of legal entity. Related to sanctions, the Government Regulation in lieu of No. 2 of 2017 contains administrative sanctions and criminal sanctions against CSOs that violate through Article 61.

In addition, Law No. 17 of 2013 is considered unable to prevent the spread of ideologies that are contrary to the Pancasila and the 1945 Constitution, both from the substantive aspects related to norms, prohibitions and sanctions as well as existing legal procedures. This is considered an emergency situation and the Government Regulation in lieu of No. 2 of 2017 has expanded the definition of understanding that is contrary to Pancasila, as stipulated in the Elucidation of Article 59 paragraph (4) of Law no. 17 of 2013 stating that: [52] "What is meant by 'teachings that are contrary to Pancasila' is atheism, communism/Marxism, Leninism, or other ideas aimed at replacing/changing Pancasila and the 1945 Constitution". [52 para 7]

The expansion of the definition of 'other ideas aimed at replacing/changing Pancasila and the 1945 Constitution' can be interpreted as an extension of teachings that threaten the ideology and foundation of the Unitary State of the Republic of Indonesia. The expansion of the phrase can effectively act against social organizations that are contrary to the Pancasila ideology and which seek to replace the Indonesian government system. However, the addition of the phrase and the expansion of the definition of 'other ideas aimed at replacing Pancasila and the 1945 Constitution' still impress. This is because, until now, there is no misunderstanding about the parameters considered contrary to Pancasila and the 1945 Constitution of the legal vacuums perceived cannot be overcome by making the law in an ordinary procedure. To do so, it will require quite a long time. The urgent situation needs certainty to be resolved is the next parameter (Third Parameter) contained in the Constitutional Court Decision

\section{Number 138/PUU-VII/2009.}

The 1945 Constitution grants the President the right to enact the Government Regulation in lieu and does not give the House of Representatives the right to make regulations in lieu of the Law, with the phrase "the President has the right" as stipulated in the provisions of Article 22 of the 1945 Constitution. If the regulation is submitted to the House of Representatives, the process will require quite a long time, because the House of Representatives as a representative body, must go through a long mechanism to decide and formulate a law. For example, from the process of taking it to the decision in the hands of members, it means to decide something must go through meetings of the House of Representatives. Thus, if it has to wait for a decision of the House of Representatives, legal needs may not be fulfilled quickly.

\subsection{Implementation of the Right to Organize in Establishing Government Regulations in Lieu of Law Number 2 of 2017 Becoming Law Number 16 of 2017}

Indonesia is a state of law. One of the characteristics that must be fulfilled by the state is the protection and guarantee of human rights for all its citizens. The concept of human rights is Indonesia's commitment to respect and guarantee the protection of human rights as embodied in the values of the Pancasila, the basis of the state and the philosophy of life of the Indonesian people. The 1945 Constitution which was born before the UDHR has a fairly progressive human rights perspective, as confirmed in paragraph I of the Preamble of the 1945 Constitution, Whereas independence is the inalienable right of all nations, therefore, all colonialism must be abolished in this world as it is not in conformity with humanity and justice."

Freedom of association is the right of humans to unite themselves with their fellow humans for a long time in order to achieve a purpose, while freedom of association is a human right to discuss a matter together. [53] Therefore, in freedom of association and assembly, there are two different and inseparable rights, namely "freedom of assembly" and "freedom of association."

When viewed from the perspective of human rights, the state has an obligation to guarantee the implementation of the right to freedom of association and regulate the protection of the right to freedom of association. In exercising such freedom of association, it must submit to restrictions, solely to guarantee the recognition and respect for human rights and the basic freedoms of others, decency, public order, and national interests.

This provision implies that the community is given an active role in the administration of the state through social organizations outside government organizations for the achievement of the development of this nation. A CSO can conduct surveillance or correction if government policies are not in line with the conditions of the community. This is a form of community participation and popular sovereignty.

The principle of freedom of expressing thought and opinion both verbally and in writing will automatically be 
paralyzed, if there is no guarantee for everyone to gather and associate. On the other hand, freedom of opinion and assembly must go hand in hand and be guaranteed by the state. [45 para19-20]

In exercising their freedom, CSOs must submit to the limitations guaranteed by the constitution as referred to in Article 28J paragraph (2) of the 1945 Constitution, stating that:

"In exercising his/her rights and freedoms, every person shall have the duty to accept the restrictions established by law for the sole purposes of guaranteeing the recognition and respect of the rights and freedoms of others and of satisfying just demands based upon considerations of morality, religious values, security and public order in a democratic society."

Pancasila serves as the basis and philosophy to wildlife nation and state, thus, CSOs shall make Pancasila as breath, soul, and spirit in managing CSOs. Recognition and respect for the Pancasila and the 1945 Constitution as the basis and philosophy of the nation and state mean respecting and recognizing the diversity of CSOs that have the principles of organizational struggle that are not contrary to the Pancasila and the 1945 Constitution, as well as CSOs that make that matter as the basis of the organization. This is a consequence of the adoption of the rule of law.

Based on the study of freedom of association and assembly as described above, a study was conducted regarding the implementation of freedom of association as stipulated in the Government Regulation in lieu of No. 2 of 2017 stipulated to be Law No. 16 of 2017 which is the core of this research study.

The Government Regulation in lieu of No. 2 of 2017 content, compared to Law No. 17 of 2003, as a substantial the Government Regulation in lieu of No. 2 of 2017, has more detailed compared to Law No. 17 of 2003, in terms of the regulations related to CSOs, the definition of CSOs which may not contrary to Pancasila, the regulations related to punishment for CSOs who violate this law will lead to administrative sanction, the regulations related to differences in the reasons dissolution of CSOs, and related settings mechanism of dissolution of CSOs. The development of these arrangements can be seen as follows:

\section{1). Arrangements related to CSO definition}

Law No. 17 of 2013 Article 1 number 1 states: "Social Organization, hereinafter referred to as CSO, is an organization that is established and formed by the community voluntarily based on shared aspirations, desires, needs, interests, activities and objectives to participate in development in order to achieve the goals of the Unitary State of the Republic of Indonesia based on Pancasila."

Whereas, the Government Regulation in lieu of No. 2 of 2017 Article 1 states: "Social Organization, hereinafter referred to as CSO, is an organization that is established and formed by the community voluntarily based on shared aspirations, wishes, needs, interests, activities, and objectives to participate in development for the achievement of the objectives of the Unitary State of the Republic of Indonesia based on Pancasila and the 1945 Constitution of the Republic of Indonesia."

The change in definition is intended as a form of recognition of the rights of community association and affirming and placing Pancasila values as the basis of state philosophy (philosophical grondslag), state ideology and way of life which are sources of values, inspiration and basic interpretations of social life, nation and state which are actualized into the process of making legislative products and various state administration policies.

2). Regulations related to the definition of understanding that are contrary to Pancasila

Elucidation of Article 59 paragraph (4) of Law No. 17 of 2013 states that "What is meant by" teachings or understandings that are contrary to Pancasila "is the teachings of atheism, communism/Marxism-Leninism. The Elucidation of Article 59 paragraph (4) letter c of the Government Regulation in lieu of No. 2 Year 2017 states: "What is meant by" doctrine or ideologies contrary to Pancasila" are the doctrine of atheism, communism/Marxism-Leninism, or other philosophies which aims to replace/change Pancasila and the 1945 Constitution."

In Law No. 17 of 2013, the notion of teachings and actions that are contrary to Pancasila is narrowly formulated, which is only limited to the teachings of Atheism, Marxism and Leninism. Whereas, in the Government Regulation in lieu of No. 2 of 2017, it is added with the phrase "or other understanding aimed at replacing/changing Pancasila and the 1945 Constitution of the Republic of Indonesia."

The addition of phrases related to other ideas aimed at replacing/changing Pancasila and the 1945 Constitution of the Republic of Indonesia is a form of internalization of the values of Pancasila, especially the principle of Indonesian unity, which implies that every legal regulation must refer to the creation of a national unity. In the empirical level, the emergence of CSOs with various forms of activity basically cannot defeat the spirit of unity and integrity of the Indonesian nation.

3). Arrangements related to criminal sanctions for violating CSOs

Law No. 17 of 2013 previously did not regulate criminal sanctions. Meanwhile, the Government Regulation in lieu of No. 2 of 2017 inserts a new chapter between CHAPTER XVII and CHAPTER XVIII, namely CHAPTER XVIIA concerning criminal provisions in Article 82A stating:

1) Every person who is a member and/or organizer of a mass organization that intentionally and directly or indirectly violates the provisions referred to in Article 59 paragraph (3) letter $\mathrm{c}$ and letter $\mathrm{d}$ shall be sentenced to a minimum of 6 (six) months imprisonment and a maximum of 1 (one) year.

2) Every person who is a member and/or organizer of a mass organization that intentionally and directly or indirectly violates the provisions referred to in Article 59 paragraph (3) letter a and letter b, and paragraph (4) shall be liable to life imprisonment or imprisonment for a minimum of 5 (five) years and a maximum of 20 
(twenty) years.

3) In addition to imprisonment as referred to in paragraph (1), the person concerned is threatened with additional penalties as stipulated in criminal legislation.

The phrase "every person" in Law No. 16 of 2017 shows that criminal sanctions can be imposed on any $\mathrm{CBOs}$ that are members and/or organizers of $\mathrm{CBOs}$ that violate the provisions in Article 59 and can be sentenced for life or imprisonment for a minimum of 5 (five) years and a maximum of 20 (twenty) years and may also be subject to additional penalties as provided for in applicable laws and regulations.

The criminal sanction is a form of limitation of rights guaranteed by the constitution, solely to prevent the emergence of ideas that try to replace Pancasila as the principle and view of the nation's life.

4). Related Administrative sanctions

Articles 62 to article 80 of Law No. 17 of 2013 regulate administrative sanctions which lead to the dissolution of CSOs. Meanwhile, the Government Regulation in lieu of No. 2 of 2017, there is replacement of the provisions of article 60 through article 62 and article 63 through Article 81, and insertion of article $80 \mathrm{~A}$, article $82 \mathrm{~A}$ and article $83 \mathrm{~A}$, and the Chapter XVIIA.

Pursuant to Article 60 of Law No. 17 of 2013, it is stated that the Government/Regional Government imposes administrative sanctions on CBOs that violate the provisions referred to in Article 21 and Article 59. Article 21 of Law No. 17 of 2013 regulates the obligations of Community Based Organization (CBOs).

So that any CSOs that violate the provisions of Article 21, Article 51, and Article 59 paragraph (1) and paragraph (2) of the Government Regulation in lieu of No. 2 of 2017, administrative sanctions will be given as stipulated in Article 61 which ends in the dissolution of CSOs. The provisions of Article 61 paragraph (3) the Government Regulation in lieu of No. 2 of 2017 explains that the administrative sanctions referred to in Article 60 paragraph (2) is revocation of a registered certificate by the Minister or revocation of the status of a legal entity by the minister who carries out governmental affairs under law and human rights. While administrative sanctions referred to in Article 60 paragraph (1) consists of written reminder, cessation of activities and/or revocation of a registered letter or revocation status of legal entity as set out in Article 61 paragraph (1) of Government Regulation No. 2 of 2017.

The restriction stipulated in Article 21, Article 51 and Article 59 paragraph (1) and (2) of Government Regulation No. 2 of 2017 can be justified as long as they are in accordance with the issues of unity, religious values, culture, morals, ethics, norms of decency, public order, and peace. Thus, if it is related to Article 73 of the Human Rights Law, the justification of the right to freedom of association is as follows:"The rights and freedoms set forth in this Law can only be limited by and based on the Act, solely to guarantee the recognition and respect for human rights and the basic freedoms of others, decency, public order and the interests of the nation".

Furthermore, if Article 21, Article 51, and Article 59 paragraph (1) and paragraph (2) the Government Regulation in lieu of No. 2 of 2017 are compared to Article 73 of the Human Rights Law, restrictions on rights regulated in the Government Regulation in lieu of No. 2 of 2017 is not contrary to the norms of decency, public order, the interests of the nation, which in this case can be interpreted as unity and integrity. Furthermore, Article 29 of the UDHR states that: "In exercising their rights and freedoms, everyone is only subject to the limitations set by law, solely to guarantee the recognition and respect for the rights and freedoms of others, and to fulfill the moral requirements, public order and fair public welfare in democratic society."

It can be seen that the restrictions on the right to freedom of association in Article 21, Article 51, and Article 59 paragraph (1) and paragraph (2) of the Government Regulation in lieu of No. 2 of 2017 is in accordance with morals, public order, public welfare, and peace. The limitation is intended as a guide for every individual or group of people, i.e. a norm with equal rights. It can be interpreted that in freedom there are general norms that apply in social life. Therefore, each human right hold by each person will face each other and must respect the rights of others who have the same rights to him. In other words, the expression of individual human rights must lead to the goal of creating harmony in life and life in society in peace and conducive situation.

5). Arrangements related to differences in the reasons for the dissolution of CSOs

Article 60 of the Government Regulation in lieu of No. 2 of 2017 states that the Government/Local Government imposes administrative sanctions on CSOs that violate the provisions referred to in Article 21 and Article 59. Article 21 of the Government Regulation in lieu states that CBOs are obliged to: carry out activities in accordance with organizational goals, maintain national unity and integrity of the Unity of the Republic of Indonesia, and maintain the values of religion, culture, moral ethics, and moral norms and providing benefits to society.

Whereas in the Government Regulation in lieu of No. 2 of 2017, one point changed is Article 59 on the prohibition of CSOs. The majority of restrictions are the same as Law No. 17 of 2013 but are grouped differently. This grouping is then related to sanctions imposed if CSOs commit violations in accordance with what has been regulated in Article 60 paragraph (1) of Law 16 of 2017 on CSOs which states that CSOs violate the provisions referred to in Article 21, Article 51, and Article 59 paragraph (1) and paragraph (2) are subjected to administrative sanctions. Meanwhile, Article 60 paragraph (2) states that CSOs that violate the provisions referred to in Article 52 and Article 59 paragraph (3) and paragraph (4) are subject to administrative sanctions and/or criminal sanctions.

In accordance with what has been regulated in Article 61 paragraph (3) of the Government Regulation in lieu of No. 2 2017 on Amendments to Law No. 17 of 2013 on CSOs, it is 
explained that the administrative sanctions referred to in Article 60 paragraph (2) are revocation of registered certificates by the Minister or revocation of legal entity status by the minister who carries out government affairs in the field of law and human rights. While administrative sanctions that referred to in Article 60 paragraph (1) consist of written reminder, cessation of activities and/or revocation of a registered letter or revocation status of legal entity as set out in Article 61 paragraph (1) of Government Regulation No. 2 of 2017 on Changes of Law No. 17 of 2013 on mass organizations. Then, the Elucidation section in Article 59 underwent a slight change in Article 59 paragraph 3 letter a which states that "What is meant by 'acts of hostility' are words, statements, attitudes or aspirations, both verbally and in writing, whether through electronic media or other media that cause hatred, both towards certain groups and against everyone including the state administration."

In order to prevent different interpretations from the community related to the enactment of the Government Regulation in lieu of No. 2 of 2017, the explanation section contains the following provisions:

a) The Government explains the ban of CSOs' conduct and authority of law enforcement in accordance with the provisions of the legislation in article 59, paragraph $3 \mathrm{~d}$ as follows: "What is meant by activities that are the duty and authority of law enforcement" is the act of arresting, detaining, and restricting one's freedom of movement because of ethnic, religious, and national backgrounds that conflict with applicable laws and regulations."

b) The prohibition on carrying out separatist activities regulated in Article 59 paragraph 4 letter b is as follows:

c) "What is meant by carrying out separatist activities is activities aimed at separating parts of or the entire territory of the Unitary State of the Republic of Indonesia or controlling parts or the whole territory of the Unitary State of the Republic of Indonesia, both on the basis of ethnicity, religion, and race."

d) Elucidation of Article 59 paragraph (4) letter c explains that the definition of doctrine or understanding that is contrary to Pancasila is not limited to atheism, communism, Marxism, and Leninism. Other understandings aiming to change Pancasila and 1945 are also prohibited, as stated below:

e) "What is meant by "teachings or understandings that are contrary to Pancasila include the teachings of atheism, communism/Marxism-Leninism, or other ideas aimed at replacing/changing Pancasila and the 1945 Constitution of the Republic of Indonesia."

Setting related to problems of different reasons dissolution of CSOs is like an attempt to reassert foundation of the Unitary Republic of Indonesia to inculcate noble values of Pancasila, national unity, and 1945 Constitution in the life of society, nation, and state. Freedom without limits will certainly be a threat to the life of the nation and state. If such a situation is not resolved, it is feared that it can undermine the concept of a unitary state agreed upon by the nation's founders. Citizens of both collectively and as individuals in the rights and freedoms are also obliged to respect the rights and freedoms of others. In this context, the state is obliged and must be able to regulate the balance and harmony between the rights and freedoms of individuals with the collective rights and freedoms of citizens.

The regulation is intended solely to guarantee the recognition and respect for the rights and freedoms of others, and the fulfillment of justice in accordance with moral considerations, socio-cultural values, religion, security, peace and public order to safeguard the sovereignty of the Unitary State of the Republic of Indonesia. Arrangements made by the Government are intended to ensure that freedom of association and assembly which are human rights for citizens must not override the rights and obligations of citizens to practice and strengthen the state ideology.

6). Regulations related to the dissolution mechanism of CSOs

If viewed from the provisions of Article 60 of Law No. 17 of 2013, it is stated that the government or regional government in accordance with the scope of their duties and authorities impose administrative sanctions on CBOs that violate the provisions referred to in Article 21 of Law No. 17 of 2013 and in Article 59 of Law No. 17 of 2013.

Based on Article 60 paragraph (2) of Law No. 17 of 2013, the government or regional government undertakes persuasive efforts before imposing administrative sanctions on CSOs who commit violations. Then, in Article 61, it is explained that the administrative sanctions referred to in Article 60 paragraph (1) consist of written warnings, termination of assistance and/or grants; temporary suspension of activities; and/or revocation of registered certificate or revocation of legal entity status.

Based on article 62 paragraph (1) letter a, written warning is given 3 times. According to Article 62 paragraph (2), written warnings as referred to in paragraph (1) are given in stages and each written warning is valid within a maximum of 30 days. Then in Article 62 paragraph (3), in the event that CSOs have complied with written warnings before the end of the period referred to in paragraph (2), the government or regional government may be able to revoke the written warning referred to. Moreover, in Article 62 paragraph (4), in the case of CSOs do not comply with a written warning of unity within the period referred to in paragraph (2), government or local government may impose the second written warning. And if the second written warning is not obeyed, the government can impose the third written warning.

In Article 64 paragraph (1), in the event that CSOs do not comply with the third written warning as referred to in Article 62 paragraph (5), and Article 63 paragraph (2), the government or regional government may impose sanctions in the form of termination of funds/grants and/or suspension of activities. Whereas, if CSOs do not receive assistance and/or grants, the government or regional government may impose sanctions on the suspension of activities as referred to in paragraph (1) letter $b$.

Article 65 paragraph (1) states that in the case of imposing sanctions on the suspension of activities against national scope 
CSOs, the government is required to request legal considerations from the Supreme Court. If within a maximum period of 14 (fourteen) days the Supreme Court does not give legal considerations, the government has the authority to impose sanctions on the suspension of activities. Stated in Article 65 paragraph (3) in the case of imposing sanctions on the temporary suspension of activities against provincial or district/city- scope CSOs, the regional head is obliged to ask for consideration of the local DPRD, the prosecutor's office and the police in accordance with the level.

Article 66 paragraph (1) explains that suspension of activities referred to in Article 64 paragraph (1) letter b is imposed for a maximum period of 6 (six) months. In the event that the period of suspension of activities referred to in paragraph (1) ends, CSOs can carry out activities in accordance with the objectives of CSOs. Article 66 Paragraph (3) states "In the event that CSOs have complied with sanctions for the temporary suspension of activities before the end of the period referred to in paragraph (1), the government or regional government may revoke sanctions for the suspension of activities."

Article 67 explains that if CSOs legal entity does not comply with sanctions, the government or local government can impose sanctions revocation of a certificate of registered by requesting the legal considerations prior to the Supreme Court. The Supreme Court is obliged to provide legal considerations in period of 14 (fourteen) days from receipt of the request for legal consideration. Article 68 paragraph (1) states that for CSOs that are legal entities do not comply with dissolution sanctions interim, the Government sanctions the revocation status of legal entity. Sanctions for revocation of legal entity status are imposed after a court ruling has obtained permanent legal force regarding the dissolution of a legal entity of mass organization. The status revocation of legal entity status is carried out by the minister who carries out government affairs in the field of law and human rights.

Article 69 explains that revocation status of legal entity CSOs is carried out within a period of 30 (thirty) days from the receipt of a copy of the decision of dissolution of CSOs by the court. Article 70 states that application for dissolution CSOs' legal entity referred to in Article 68 paragraph (1) shall be submitted to the court by the prosecutor only upon the written request of the minister who held government affairs in the field of law and human rights.

In article 71, it is explained that the request for dissolution of a Mass Organization must be decided by the District Court within a period of no later than 60 (sixty) days after the application is recorded. This period can be extended for a maximum of 20 (twenty) days with the approval of the Supreme Court. Regarding the District Court's ruling, only legal action can be appealed in accordance with Article 73 of Law No. 17 of 2013 on Mass Organizations. While the nature of Government Regulation No. 2 of 2017 is related to the act of CSOs who violate it in which CSOs will be penalized in the form of administrative sanctions and/or criminal sanctions as set out in Article 60 as follows:

1. CSOs that violate the provisions referred to in Article 21,
Article 51, and Article 59 paragraph (1) and paragraph (2) are subjected to administrative sanctions, and

2. CSOs that violate the provisions referred to in Article 52 and Article 59 paragraph (3) and paragraph (4) are subjected to administrative sanctions and/or criminal sanctions.

For CSOs that commit violations according to the provisions of Article 60 paragraph (1) are subject to administrative sanctions as stipulated in Article 61 paragraph (1) consisting of:

a) Written warning,

b) Termination of activities, and/or

c) Revocation of registered certificate or revocation of legal entity status.

The form of a written warning is only given once within a period of seven working days after the warning issued. If CSOs do not comply with a written warning within the time specified, the minister that is responsible in the field of law and human rights in accordance issues sanction of termination of activities.

In the event that CSOs do not comply with the sanctions to stop the activities, the minister revokes the registered certificate or revokes the status of the legal entity. Whereas CSOs who commit violations in accordance with Article 60 paragraph (2) are subject to administrative sanctions and/or criminal sanctions. Administrative sanction is revocation by the minister conducting government affairs in the field of law and human rights. [54]

Law No. 16 of 2017 on Stipulation of the Government Regulation in lieu of No. 2 of 2017 deleted several articles and inserted a number of provisions as substitute articles. At least 19 articles were deleted including Article 63 until the premises of Article 81 and inserted Article 80 A stating "The revocation status of legal entity of organizations is referred to in Article 61 (1) c and (3) b once it is declared dissolved by Government Regulation in Lieu of Law - this Act."

The sanctions stipulated in Article 60 paragraph (2) of Law No. 16 of 2017 are not tiered, so that it can be directly on the revocation of registered certificates or revocation of legal entity status without going through written warnings and/or termination of activities, and even without having to wait for a decision court. This is confirmed in the explanation of Article 61 paragraph (3) letter b which states:

"What is meant by "the imposition of administrative sanctions in the form of revocation of registered certificates and revocation of legal entity status" is sanctions that are direct and can immediately be implemented by the Minister of the Home Affairs or Minister of Law and Human Rights against CSOs whose principles and activities clearly threaten sovereignty of the Unitary State of the Republic of Indonesia are based on the Pancasila and the 1945 Constitution of the Unitary State of the Republic of Indonesia, so that the Government is authorized to revoke. Revocation of registered certificate and revocation of the legal entity status of CSOs are in accordance with the principle of contarius actus, so that officials authorized to issue certificates/decree also have 
the authority to revoke."

Government Regulation No. 2 of 2017 which has been stipulated as Law 16 of 2017 adheres to the principle of contractus actus. However, in the case of dissolution of CSOs regulated in this law, there are no judicial procedures and mechanisms available. In the decision of the entrepreneurs in disbanding such CSOs, there are parties who feel object and the minister's decision can still be tested through a court of law in the State Administrative Court (PTUN). Regarding the Government Regulation in lieu of No. 2 of 2017 in its transitional provisions state that at the time the Government Regulation in lieu of comes into force, all laws and regulations which constitute implementing regulations of Law No. 17 of 2013 is declared to remain valid as long as it does not conflict with the provisions in the Government Regulation in lieu of No. 2 of 2017. In this case, Government Regulation Number 58 of 2016 on Implementation of Law Number 17 of 2013 on Community Organizations, Minister of Home Affairs Regulation Number 56 of 2017 on Supervision of Community Organizations in the Environment Ministry of Home Affairs and Minister of Home Affairs Regulation Number 57 of 2017 on Registration and Management of Community Organization Information Systems remain to be applied today as an implementing regulation of the Law of CSOs.

In the implementation of the right of association in forming CSOs, the implementing regulations of Law No. 17 of 2013 which is declared still valid is in accordance with and in line with the spirit of stipulation of the Government Regulation in lieu of No. 2 of 2017 as amended to become Law Number 16 of 2017. Regulation of Ministry of Home Affairs No. 57 of 2017 has regulated in detail the procedure for registration for CSOs, including legal or non-legal organizations, to avoid and at the same time filter out potential radical and anti-Pancasila organizations. Article 1 of the Regulation of Ministry of Home Affairs No. 57 of 2017 explains that the definition of limitation of registration regulated in this regulation is a process of recording a mass organization which is not a legal entity for recording in government administration with certain requirements to be given SKT by the Minister. This is certainly a form of supervision and prevention from the government to be able to implement the protection of the right of association for citizens, but it cannot be separated from the observation of the authorities. The government does not prohibit or take the right of association of citizens to form an organization, but on the other hand also requires CSOs to register and obtain SKT through this regulation.

In the Constitutional Court Decision related to Law No. 17 of 2013, Decision Number 82/PUU-XI/2013 whose ruling states that Article 16 paragraph (3), Article 17, Article 18, Article 23, Article 24, and Article 25 of Law No. 17 of 2013 are contrary to the 1945 Constitution and has no binding legal force. The consequence of the cancellation of these articles by the Constitutional Court is that the government cannot ultimately force or require non-legal organizations to register themselves or have a Registered Certificate (SKT) based on the working area and national, provincial, and district/city scope.

The SKT instrument is used as a means of monitoring and supervising freedom of association for the community. However, on the other hand, the Constitutional Court's decision gives freedom to CSOs who are not legal entities to register. In addition, they are not prohibited if they do not register themselves and when CSOs are not legally elected and choose not to register themselves. In this case, the government must continue to recognize and protect its existence as a CSOs that can carry out activities in regional and national scope.

If it is associated with the implementation of the right to freedom of association, the Government Regulation in lieu of No. 2 of 2017 which has been determined to be Law No. 16 of 2017 and the implementing rules and regulations of ministerial terms of substance have been already in harmony to keep providing the right to freedom of association to citizens with restrictions and supervision tightened.

Therefore, the freedom to associate, freedom of association, and freedom of expression through mass organizations must obtain legal legitimacy in the form of manifestation in legislation to accommodate the freedom of each individual and group in exercising their freedom. The freedom guaranteed by the constitution is not free freedom, but freedom that is responsible and in accordance with applicable laws and regulations. This means that the freedom contained therein may not injure the values of decency, order, and national integrity, as well as religious values. This commitment is contained in the article on human rights concerning the right to advance themselves and fight for their rights collectively for the people, nation, state and freedom to believe, to express their thoughts and behave according to conscience, and the right to associate and hold opinions. [55]

\section{Conclusion}

The basis for consideration of coercive circumstances or 'forced urgency' as the basis for establishing the Government Regulation in lieu of No. 2 of 2017, as contained in the Considerations for letters $\mathrm{c}$ and $\mathrm{d}$ of the Government Regulation in lieu of No. 2 of 2017 has met the formal and material requirements of the stipulation of the Government Regulation in lieu. Certain CSO activities that have carried out acts of hostility include words, statements, attitudes or aspirations both verbally and in writing, through electronic media or other media, which incites hatred both towards certain groups and against those who belong to the state administrators. This action is potential to cause social conflict between community members so that it can result in chaotic situations that are difficult to prevent and overcome by law enforcement officials. This situation can be categorized as an emergency situation that can threaten the sovereignty of the Unitary Republic of Indonesia based on the Pancasila and the 1945 Constitution and threats to the future life of the Indonesian people and the existence of the 
Unitary State of the Republic of Indonesia.

In addition, there has been a legal vacuum in the application of effective sanctions against CSOs that are in conflict with the Pancasila and the 1945 Constitution. This is what prompted immediate changes to Law No. 17 of 2013 which is seen as not yet comprehensively regulating the provisions related to effective sanctions. In addition, Law No. 17 of 2013 is seen as unable to prevent the spread of ideologies that are contrary to the Pancasila and the 1945 Constitution, both from the substantive aspects related to norms, prohibitions and sanctions as well as the existing legal procedures. This is considered an emergency situation and the Government Regulation in lieu of No. 2 of 2017 has expanded the definition of understanding that is contrary to Pancasila.

The Government Regulation in lieu of No. 2 of 2017 which has been stipulated as Law No. 16 of 2017 is basically formed as an effort to regulate the balance and harmony between the rights and freedoms of individuals with the collective rights and freedoms of citizens in carrying out their freedom of association and forming CSOs. In carrying out these obstacles, CSOs must comply with limitations guaranteed by the constitution, Pancasila, and statutory provisions.

Implementation of the Government Regulation in lieu of No. 2. In 2017 has fulfilled the formal and material elements of the formation of the Government Regulation in lieu, which has fulfilled elements that include the existence of an urgent need to act or reasonable necessity, the existence of an element of force and the occurrence of a legal vacuum, and the stipulation of the Government Regulation in lieu only way to overcome the situation. In order to prevent violations of freedoms of assembly and association guaranteed by the constitution, it is necessary to do check and balance measures through judicial institutions' considerations in the application of the Government Regulation in lieu of No. 2 of 2017 as an effort to prevent a single interpretation by the authorized executive.

In order to counteract the growing acts of radicalism and ideologies contrary to the ideology of Pancasila, the necessary preventive efforts involve specialized institutions such as BPIP in providing surveillance and education Pancasila for organizations in Indonesia, through coordination, synchronization, and control fostering the ideology of Pancasila as a whole and continuously. BPIP is also responsible for providing education and training in order to keep upholding the values of Pancasila in carrying out its organization. Relying on sanctions in the form of revocation of SKT by the Minister is felt it will only function as a repressive measure. Therefore, the authors suggest to strengthen preventive measures by instilling the Pancasila ideology in Indonesian mass organizations through the involvement of BPIP.

\section{References}

[1] The 1945 Constitution of Indonesia with the fourth amendment.

[2] Law Number 39 of 1999 of the Republic of Indonesia concerning Human Rights.
[3] Hasani. I, Naipospos, B. T. Religious Radicalism in Jabodetabek \& West Java: Implications for Guarantees of Freedom of Religion/Belief. (Jakarta: Pustaka Masyarakat Setara, 2010), p. 5.

[4] Mufid, A. S. Map of Radicalism Movement in Indonesia, Workshop Presentation Paper Building Awareness and Strategies in Facing Religious Radicalization, (Palu, 22 May 2012), p. 8 .

[5] Budiyanto, H. et al., Social Organizations, (In the FKIP UMS Surakarta Seminar, 2008), p. 10.

[6] Arinanto, S. Human Rights in Political Transitions in Indonesia, (Jakarta: Faculty of Law, University of Indonesia 2018). p. 21.

[7] Purwaka, T. H. Legal Research Methodology, (Jakarta: Atmajaya University Publisher (PUAJ), 2007), p. 49.

[8] Krabbe, H. et al, The Modern Of The State, (The Hague: Martinus Nijhoff, 1922), p. XVIII.

[9] Strong, CF. Modern Political Constitutions "Constitutions of State Politics" Comparative Study of History and Form, translated by Derta Sri Widowatie, (Bandung: Nusa Media, 1966), p. 8.

[10] Salim, H. HS, Theory Development in Law, (Jakarta: Raja Grafindo Persada, Second Printing, 2012), p. 135.

[11] Affandi, M. Association of State Studies, (Bandung: Alumni, 1971), pp. 166-167.

[12] Hartono, S. What Is The Rule Of Law?, (Bandung: Alumni, 1969), p. 45.

[13] The Writers' Team, Building a Dignified Law State, (Malang: Setara Press, First Printing Edition, 2013), p. 157.

[14] Hadjon, P. M. Legal Protection for the People in Indonesia "a study of its Principles, Their Handling by the Courts in the General Judicial Environment and the establishment of State Administrative Courts, (Surabaya; Bina Ilmu, First Matter, 1987), p. 72.

[15] Yamin, M. Proclamation and Constitution..., quoted by Azhary, Indonesian Law State Normative Yurids Analysis of Its Elements, (Jakarta: UI Press, 1995), p. 31.

[16] Mahfud M. MD, Constitution and Law in the Controversy of Issues, (Jakarta: Rajawali Press, 2010), p. 384.

[17] Asshiddiqie, J. Principles of Rule of Law, In " Some Aspects of State Administration, Criminal Law, and Islamic Law, Welcoming 73 Years of Prof. Dr. H. Muhammad Tahir Azhary, (n. d), p. 28-29.

[18] Mahfud M. MD, Debate on Constitutional Law Post Constitutional Amendments, (Jakarta: LP3ES, 2007), p. 51.

[19] Utrecht, Introduction to Indonesian State Administrative Law, (Jakarta: Ichtisar, 1962), p. 9.

[20] Friedman, W. Law in a Changing Society, as quoted by Jimly Asshiddiqie, Principles of the Law of Indonesia, in Some Aspects of Constitutional Law..., p. 28.

[21] Arinanto, A. et al., Ed., Human Rights Law, (Yogyakarta: Center for Human Rights Studies at the Islamic University of Indonesia, 2008), p. 14. 
[22] Antonius Cahyadi. A., Manulang, E, F, M. Introduction to the philosophy of Law, (Jakarta: Kencana, print 2, 2008), p. 42.

[23] Asshiddiqie, J. Constitutional Law and Pillars of Democracy, Op. Cit., P. 211

[24] Hisbulloh, H. (n. d) Analysis of Perpu Ormas. Retrieved from: https://www.academia.edu/35218024/ANALISIS TENTANG _PERPPU_ORMAS.

[25] Utari, S. Freedom of Association and Gathering (A Study of Regulations on Political Parties in Indonesia), (Jakarta: Postgraduate Program at the Faculty of Law, University of Indonesia, 2004), pp. 44-45.

[26] Soekanto. S., Mamuji. S. Legal Research Normative A Brief Overview, Molds to - 11. (Jakarta: King Grafindo Persada, 2009), pp. 13-14.

[27] Prasetyo. T. and Abdul Halim Barkatullah, Philosophy of Theory, and Legal Studies: Thought Towards a Fair and Dignified Society, (Jakarta: Raja Grafindo Persada, 2012), p. 367.

[28] Flores, I. B. "Legisprudence, The Role and Rationality of Legislators - Vis a Vis Judges - Towards the Realization of Justice ", (Mexican Law Review, New Series Volume 1, Number 2, 2009), p. 107.

[29] Bauman. R. W., Kahana. T. (ed), The Least Examined Branch, The Role Of Legislatures In The Constitutional State, (Cambridge: Cambridge University Press, 2006), pp. 17-18.

[30] Justice Forum. No. 19. August 12, 2001. p. 14.

[31] Suny, I. Shift in Executive Power. (Jakarta: New Script. 1986), p. 61.

[32] C. Fatovic. Constitutionalism and Presidential Prerogatives: Jeffersonian and Hamiltonian perspective. (American Journal of Political Science, 48 (3). 2004), p. 429.

[33] Mahfud MD, M. Law and Pillars of Democracy. (Yogjakarta: Gama Media, 2010), p. 256.

[34] Rositier, C. Constitutional Dictatorship. (New Jersey: Princeton University Press, 1948), p. 9.

[35] Law Number 12 of 2005 concerning Ratification of the International Covenant on Civil and Polical Rights (International Covenant on Civil and Political Rights).

[36] Kuntowijoyo in Saldi Isra. "Strengthening and Guarding Pancasila in the Legislation Process (Jakarta: National Law Magazine. 2015), p. 61.

[37] Isra. S. "Strengthening and Guarding Pancasila in the Legislation Process ". (Jakarta: National Law Magazine. 2015), page 63.

[38] Assiddiqie, J. Freedom of Association, Dissolution of Political
Parties, and the Constitutional Court, (Jakarta: Constitution Press, 2005), p. 9.

[39] Siahaan, M. Freedom of Association and Peaceful Gathering and Its Implications, Institut Leimena, July 2011, https://leimena.org/blog/2011/07/06/keb Freedom- unitedand- change-uu-ormas- 3 / Retrieved 2 April 2020.

[40] Government Regulation in Lieu of Law Number 2 of 2017 concerning Amendment to Law Number 17 of 2013 concerning Community Organizations.

[41] Basuki, T. Community Organization in Indonesian Democracy, Serial Online July-Aug, http://www.leimena.org/id/page/v/537/organizational-dalamdemocracyindonesia, Retrieved 12 April 2020.

[42] Rodhi, M. M. Tsaqofah and the Hizb ut-Tahrir Method in Establishing a Khilaf State (Bogor: Al-Azhar Fresh Zone Publishing, 2012), p. 23.

[43] Hilmy, M. "The Roots of Islamic Transnationalism of Hizb utTahrir Indonesia ". (In Journal of Islamica, Vol. 6, No. 1, September 2011), pp. 1-2.

[44] Gatra, South Jakarta District Court Freezes JAD 31 July.

[45] Article 22 paragraph (1) of the 1945 Constitution of the Republic of Indonesia.

[46] Asshiddiqie, J. Emergency State Administration Law, (Jakarta: Raja Grafindo Persada, 2007), p. 13.

[47] Asshidiqie, J. Regarding the Law. Jakarta: Rajawali Press, 2010, p. 213.

[48] Soeprapto, M. F. I. Science of Basic Law and its Development, Yogyakarta, Kanisius, 199, p. 131.

[49] Manan, B., Magnar, K. Some Indonesian Constitutional Law Issues, Bandung: Alumni, 1993, p. 150-151.

[50] Government Regulation (Perpu) No. 2 of 2017 concerning Amendments of Law Number 17 of 2013 on Community Organization.

[51] Article 12 of the 1945 Indonesian Constitution.

[52] Article 59 paragraph (4) of Law No. 17 of 2013.

[53] Amanwinata, R. "Arrangements and limits on the implementation of Freedom of Association and Association in Article 28 of the 1945 Constitution" Dissertation, (Bandung: Padjajaran University, 1996), pp. 16-17.

[54] Article 61 paragraph (3) of Law 16 of 2017 concerning Mass Organizations.

[55] Article 23 paragraph (2) of Law No. 39 of 1999 concerning Human Rights. 